\title{
Assessing Play Equality in Malaysian Public Playground through Universal Design Principle
}

\author{
Nurul Asyikin Mohd Radzi ${ }^{1}$, Kharizam Ismail2, \\ Lilawati Ab Wahab²
}

1 Faculty of Architecture, Planning and Surveying, Universiti Teknologi MARA, Shah Alam, Malaysia

2 Faculty of Architecture, Planning and Surveying, Universiti Teknologi MARA, Perak Branch, Seri Iskandar, Malaysia

nurulasyikinradzi@gmail.com , khari511@perak.uitm.edu.my , lilawati@perak.uitm.edu.my

Tel: +60125484902

\begin{abstract}
The outdoor play setting is often ignored as a viable place to accommodate children with disabilities, limiting or completely excluding them from playing like other ordinary children. Thus, this study aims to determine the integration of Universal Design (UD) qualities and the applicability of Malaysian Standard (MS 966; 2017) in Malaysia's public playground. The physical site observation process has been conducted at three (3) public playgrounds for children with disabilities in Malaysia. The findings showed that there are 8 components of the UD principle, and MS966:2017 has been violated in the playground design.
\end{abstract}

Keywords: Universal Design, Public Playground, Children with disabilities.

eISSN 2514-751X @2020 The Authors. Published for AMER ABRA cE-Bs by e-International Publishing House, Ltd., UK. This is an open access article under the CC BY-NC-ND license (http:///creativecommons.org/licenses/by$n c-n d / 4.0 /$ ). Peer-review under responsibility of AMER (Association of Malaysian Environment-Behaviour Researchers), ABRA (Association of Behavioural Researchers on Asians / Africans / Arabians) and cE-Bs (Centre for Environment-Behaviour Studies), Faculty of Architecture, Planning \& Surveying, Universiti Teknologi MARA, Malaysia.

DOI: https://doi.org/10.21834/ajebs.v5i17.372 


\subsection{Introduction}

Since 1989, play has been recognized as a fundamental human right of all children, and it has been enshrined in the United Nations Convention on the Rights of the Child under Article 13. Besides, playgrounds, playpark, and play area have been built worldwide since the nineteenth century to specifically support children's play. However, although huge strides have been taken in the provision and allocation of playgrounds for children, not every child can share the same experience. For certain children with disabilities, playing with other children on a playground, even peers with no disabilities, is seldom or never.

The lack of inclusion in design or UD in most projects has resulted in ignoring the disabled individuals' needs, especially the children (Jafari, 2014). To date, the insufficient consideration of inclusion in the playground design has caused many children with disabilities to face difficulties in accessing activities in such playgrounds. Bakar (2002) supported this statement, stating that the provision of children playgrounds in many public parks in Malaysia suffers from a lack of attention to users and ecological needs. Even though regulatory design guidelines such as Kuala Lumpur Structure Plan 2020 have established the minimum standard of provision of facilities and utilities, the existing playgrounds showed that most designers tend to only follow the base minimum, which is frequently insufficient to provide necessary accessibility (Fernelius, 2017). Besides, in due course to resolve this inequality issue, the government also has revised several standards on playground such as Malaysian Standards, i.e., MS 1331:2003 Code of Practice on Access for Disabled Persons Outside Buildings (1st revision) and MS 966: 2017; Playground Equipment - Safety Performance for public use - Specification ( $2^{\text {nd }}$ revision), but the implementation of this standard is still low (Ling et al., 2019).

According to Ayatac (2017), even if these children managed to reach public playgrounds, they are not adequately welcome to play as the equipment provided does not support their particular needs. The number of the playground that can meet their special needs are scarce in number. Besides, a study by Fernelius (2017) interviewing the children with disabilities felt that they have felt excluded at the playground, often feeling like spectators, watching other kids play and interact but not participating themselves. These children with disabilities feel this absence of inclusion on the playground was due to their decreased ability to utilize the available equipment and materials. In addition, these children also missed their valuable play experience due to the parent's fears of safety and injury, which directly poses a limitation on children with disabilities' participation in the playground.

On another point of view, many researchers also agreed that's the exclusion does not only happen to children with disabilities due to their limited access to the equipment, but they also faced social exclusion as these disabled children are 'essentially' different from normal children (Clarke, 2006; Connors and Stalker, 2007). This is proved in a study by Jing (2019), who found that only a few numbers of non- disabled children are willing to interact and communicate with children with disabilities. The absence of socio-spatial or segregated facilities in the playground also places barriers for these children with disabilities to develop peer interaction. 
Creating an inclusive playground is not only aimed to provide physical opportunities for play but also social opportunities. It should be stressed that disability cannot be considered in isolation. Thus, in the effort of giving meaningful play experiences and environments that conducive to the health and growth of children with all abilities, the setting of public playground needs to be extended compliant with the UD principles so that everyone feels belongs.

\subsection{Literature Review}

\subsection{Children with Disabilities (CWD)}

Children with disabilities are among the most marginalized and a group of people who have exclusion from society. The Persons with Disabilities Act 2008 (Act 685) (PWDA) characterizes PWDs as people with long term physical, mental and intellectual disabilities that prevented them from fully participating in a normal way in the community way of life (Isa et al., 2016; Mokhtar and Tah, 2016). WHO and World Bank (2018) estimated that there are $15 \%$ or equal to 1 billion of the world's population live with some form of disabilities. As for Malaysia, the number of registrations of PWDs is dramatically increased from year to year the number of rolls of PWDs was increased gradually from 264,448 in 2013 to 549,554 in 2019 (Social Welfare Department 2013; 2014; 2015; 2016; 2017; 2018; 2019). By June 2019, it is reported that among 549,554 registered PWDs, there were 7030 CWDs who age not more than 12 years old, and 232 of them have disabilities in hearing, 206 in visual, 52 in verbal, 644 in physical, 5449 in learning, 14 in mental and 433 in others disability. However, these numbers are fragmented as people with disabilities in Malaysia are not compulsory and are only done based voluntarily (Islam, 2015). But still, the number of CWDs in Malaysia is believed to escalate due to population aging and giving rise to the need of individuals with disabilities, especially their need in term of accessibility.

Table 1: Number of registration of PWDs in 2013-2019.

\begin{tabular}{c|c}
\hline Year & $\begin{array}{c}\text { Number of registered } \\
\text { people with disabilities }\end{array}$ \\
\hline 2013 & 264448 \\
2014 & 318132 \\
2015 & 365677 \\
2016 & 409269 \\
2017 & 420201 \\
2018 & 513519 \\
2019 & 549554 \\
\hline
\end{tabular}

Sources : Social Welfare Department 2013; 2014;2015; 2016; 2017; 2018; 2019 


\subsection{Relevant Legislation, Statutory, and Guidelines}

Some scholars claimed that UD has already been integrated into Malaysian law, standards, and guidelines (Jafari, 2014; Yusof, 2016).

There are actually few legislations, statutory and guidelines that the government has established for these PWDs. Some of them are, The Person with Disabilities Act 2008 (Act 685) , Malaysian Standards, i.e., MS 1331:2003 Code of Practice on Access for Disabled Persons Outside Buildings (1st revision) and MS 966: 2017; Playground Equipment Safety Performance for public use - Specification ( $2^{\text {nd }}$ revision). However, comparable to the world, the UD concept's implementation through legislation and standards primarily focuses on accessibility for disabled people.

\subsection{History of Playground}

Children's playground at the most basic level can be defined as a play area. The playground is much more than a play area as the playground's meaning can be different through age and technology advancement. In 1973, the playground's definition was not more than a large combination of large playthings in galvanized steel, which set together in some primitive jungle setting to provide children opportunities to exercise free play (Ellis, 1973; Prellwitz, 2007a). The playground's design limits the only place to run around and "blow of steam," lacking creative activity and causing children to develop those not arouse in a constructive way (Prellwitz, 2007b). While today, in the era of new technologies, the definition of the playground has widened to an open area that consists of a creative play system that served as a place for developing and honing motor skills and helping to meet children's social needs and skills.

\subsection{Current condition of children's playground}

According to Talay et al. (2010), to meet children with disabilities' needs, the provision of appropriate space and material to play is significant. However, a large portion of almost all existing playgrounds in Malaysia is not suitable to be used by children with disabilities from many aspects. The fact that the playground design and the play equipment are not intended for children with disabilities with limited mobility are given as obstacles (Talay et al., 2010). One of the reasons that cause limited mobility in playgrounds to children with disabilities is the ground cover. Sand or gravel was usually used as surface material. This type of material usually causes difficulty for children with disabilities to reach the playground, especially the wheelchair user, as sand seems impossible for them to traverse (Ayatac, 2017). Besides, in a study by Prellwitz (2007a), these children expressed that most playground pieces of equipment were unreasonably small to maneuver around if they had some sort of mobility device. For example, disabled children with wheelchairs may be facing difficulties in entering and getting out of the playhouse because of the playhouse size. Thus, considering space in the playground design is fundamental to enable these physically challenged children to utilize the equipment and explore the playground.

Besides, a study conducted by Jafari, (2014) highlight that children with disabilities participate in fewer activities and interact less often than other children as play equipment 
provided on the playground are not usable to these population. Most of the time, these children with disabilities can only enjoy open space surrounding the playground rather than playing with the playground components. According to Ripat and Becker (2012), building a playground for disabled children is not easy. Many standard playground activities such as swinging, climbing, and others may require physical challenges. This subsequently explained why the usability of public playgrounds for children with disabilities is limited.

In addition, unlike ordinary children's playground, playground for children with disabilities may require additional safety consideration. Zain and Mokhtar (2012) highlighted that in Malaysia, about 3000 cases of injuries happen at the playground every three months, and this commonly involved children between $5-9$ years of age. $75 \%$ of injuries that occur on playgrounds resulted from falling while playing, and $50 \%$ of all playground injuries were equipment related (Md.Saaid, 2016). This somehow explains why majority of parents who have disabled children become overcautious or overprotective when it comes to their kid's safety, especially on the playground.

\subsection{Inclusive Playground (UD concept)}

To promote the integration of children with disabilities into society, the concept of inclusive playground or application of UD has increased interest within many organizations (Prellwitz, 2007a). Early in its history, the idea of UD suffered from a lack of established criteria defining what makes the design most widely usable (Preiser and H.Smith, 2011). In such a way, catering for children with disabilities is often seen as an afterthought in the playground provision. According to (Houle 2002; Goltsman and Driskell, 1992), UD should consider all kinds of sensory perception, all forms of locomotion, and all physical and intellectual functioning levels when selecting a site, designing a building, or planning a system. The main key is to provide environmentally flexible design elements to meet the needs of various levels of ability. Thus, in 1998, Follette, James, and Ronald from the Centre for Universal Design have conducted research and introduced seven founding principles that are fundamental to meets universal design standards.

1. Equitable use - ensure the design is useful and marketable to people of all abilities. The playground design must avoid any segregating or stigmatizing to any users (Story, 1998). For example, using stairs or a ladder is not usable by everyone.

2. Flexibility in use - the design of a particular building or product should oblige a wide scope of individual preferences and abilities. These happen when the playground can offer a variety of choices to users in utilizing the playground equipment (Skulski, 2014)

3. Simple and Intuitive use - The playground's design should be straightforward, easy to understand regardless of the user's experience, knowledge, language aptitudes, or current concentration level (Follette, James, and Ronald, 1998). 
4. Perceptible Information - The design should maximize the 'legibility' of essential information. The structure should convey essential data effectively to the user, regardless of ambient conditions of the user's sensory capacities (Preiser et al., 2011).

5. Tolerance of Error - The design of the playground should minimize any possible hazards and the adverse consequences of accidental or unintended action.

6. Low Physical Effort - The concept of intense physical effort underlines nature in which people can use the environment with little exertion or fatigue (Skulski, 2014). For example, utilizing play equipment could be physically challenging for children with disabilities and require additional effort. Still, there should not be any unnecessary obstacles to accessing or approaching the play equipment.

7. Size and space for approach and use - Proper size and space must be provided for approach, reach, control, and use regardless of the user's physical characteristic and mobility.

\subsection{Evaluation of Inclusive Playground in Malaysia}

Data concerning the number of children with disabilities in all respect in Malaysia remains unreliable. As registering with the department is not compulsory, many parents refused to register their children as they are afraid their children will be ostracized by society. The most relevant figure is still taken from the 2011 World Disability Report, which indicates that $5.1 \%$ of children of age 0 to 14 years old have a disability and about $0.7 \%$ of those disabled children experience severe disability.

While the number of disabled children keeps growing year by year, UNICEF's (2018) research emphasizes that children's playground in Malaysia is still inadequate in terms of quality and quantity. Besides, first Malaysia's inclusive playground was only constructed in 2011, Youth Park Accessible Playground, Georgetown Penang. UD integration in the children's playground is then continued in the Aman Park Playground, Petaling Jaya Selangor, 2015. This clearly shows the mismatch between the rate of disabled children in Malaysia and inclusive playgrounds to fulfil these children's needs.

\subsection{Methodology}

Youth Park Accessible Playground Georgetown Penang, Titiwangsa Lake Playground Kuala Lumpur, and Aman Park Playground Petaling Jaya Selangor has been selected as study sites. These three parks were analyzed by making the physical onsite observation. The checklist was developed and localized based on the previous literature review.

\subsection{Results and Discussions}




\subsection{Analysis Based on Malaysian Standard 966:2017: Playground Equipment - Safety performance for public use.}

Table 2: Applicability of MS966:2017 in the inclusive public playground in Malaysia

\begin{tabular}{|c|c|c|c|c|}
\hline \multirow{2}{*}{$\begin{array}{c}\text { MSS } \\
\text { 966:2017 } \\
\text { Requirement }\end{array}$} & \multirow{2}{*}{ Minimum requirement } & \multicolumn{3}{|c|}{ Comparison to the case studies } \\
\hline & & $\begin{array}{c}\text { Playground } \\
\text { A }\end{array}$ & $\begin{array}{c}\text { Playground } \\
\text { B }\end{array}$ & $\begin{array}{c}\text { Playground } \\
\text { C }\end{array}$ \\
\hline $\begin{array}{l}\text { Classification } \\
\text { of age }\end{array}$ & $\begin{array}{l}\text { 1a. Play area designed for the } \\
\text { specific age group ( } 2 \text {-to } 5 \\
\text { years old, } 5 \text { - to } 12 \text { year old, } 2 \text { - } \\
\text { to } 12 \text { years old). }\end{array}$ & 1a. Yes & 1a. No & 1a. No \\
\hline $\begin{array}{l}\text { Accessible } \\
\text { route }\end{array}$ & $\begin{array}{l}\text { 2a. The routes should connect all } \\
\text { the play components } \\
\text { 2b. Accessible access and } \\
\text { egress } \\
\text { 2c. The pathway should be free } \\
\text { from any obstacle } \\
\text { 2d. The minimum clear width of } \\
\text { 1520 } \\
\text { 2e. Maximum slope 1:20 }\end{array}$ & $\begin{array}{ll}\text { 2a. } & \text { Yes } \\
\text { 2b. } & \text { Yes } \\
\text { 2c. } & \text { Yes } \\
\text { 2d. } & \text { Yes } \\
\text { 2e. } & \text { Yes }\end{array}$ & $\begin{array}{l}\text { 2a. No } \\
\text { 2b. No } \\
\text { 2c. No } \\
\text { 2d. Yes } \\
\text { 2e. Yes }\end{array}$ & $\begin{array}{l}\text { 2a.Yes } \\
\text { 2b.Yes } \\
\text { 2c.Yes } \\
\text { 2d.Yes } \\
\text { 2e.Yes }\end{array}$ \\
\hline $\begin{array}{l}\text { Clear floor } \\
\text { space }\end{array}$ & 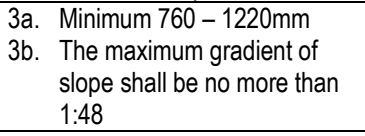 & $\begin{array}{ll}3 a & \text { Yes } \\
\text { 3b } & \text { Yes }\end{array}$ & $\begin{array}{l}\text { 3a. Yes } \\
\text { 3b. Yes }\end{array}$ & $\begin{array}{ll}3 a & \text { Yes } \\
3 b & \text { Yes }\end{array}$ \\
\hline Turning space & $\begin{array}{l}\text { 4a. Minimum radius } 1520 \mathrm{~mm} \\
\text { 4b. Wheelchair user should be } \\
\text { able to make a } 180 \text {-degree } \\
\text { turn }\end{array}$ & $\begin{array}{ll}\text { 4a. No } \\
\text { 4b. No }\end{array}$ & $\begin{array}{l}\text { 4a. Yes } \\
\text { 4b. Yes }\end{array}$ & $\begin{array}{l}\text { 4a. Yes } \\
\text { 4b. Yes }\end{array}$ \\
\hline $\begin{array}{l}\text { Ramps for the } \\
\text { elevated } \\
\text { playground } \\
\text { structure }\end{array}$ & 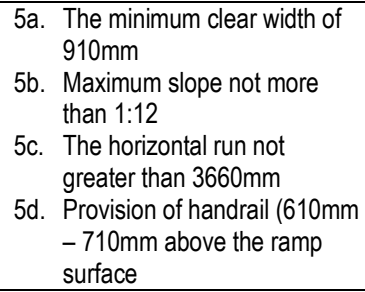 & $\begin{array}{ll}\text { 5a. } & N A \\
\text { 5b. } & \text { NA } \\
\text { 5c. } & \text { NA } \\
\text { 5d. } & \text { NA }\end{array}$ & $\begin{array}{l}\text { 5a. Yes } \\
\text { 5b. Yes } \\
\text { 5c. Yes } \\
\text { 5d. Yes }\end{array}$ & $\begin{array}{l}\text { 5a. Yes } \\
\text { 5b. Yes } \\
\text { 5c. Yes } \\
\text { 5d. Yes }\end{array}$ \\
\hline $\begin{array}{l}\text { Transfer } \\
\text { platform }\end{array}$ & $\begin{array}{l}\text { 6a. Height from the ground } \\
\text { surface shall be } 200 \mathrm{~mm} \\
\text { 6b. The minimum size of } 360 \mathrm{~mm} \\
\text { deep and } 610 \mathrm{~mm} \text { in width }\end{array}$ & $\begin{array}{l}\text { 6a. Yes } \\
\text { 6b. Yes }\end{array}$ & $\begin{array}{l}\text { 6a. Yes } \\
\text { 6b. Yes }\end{array}$ & $\begin{array}{l}\text { 6a. NA } \\
\text { 6b. NA }\end{array}$ \\
\hline Transfer steps & $\begin{array}{l}\text { 7a. Level surface } \\
\text { 7b. Step shall not trap water or } \\
\text { debris } \\
\text { 7c. Tread width shall be between } \\
410 \mathrm{~mm} \text { to } 530 \mathrm{~mm} \\
\text { 7d. The minimum tread depth is } \\
\text { 178mm } \\
\text { 7e. The maximum vertical rise is } \\
229 \mathrm{~mm}\end{array}$ & $\begin{array}{ll}\text { 7a. } & \text { NA } \\
\text { 7b. } & \text { NA } \\
\text { 7c. } & \text { NA } \\
\text { 7d. } & \text { NA } \\
\text { 7e. } & \text { NA }\end{array}$ & $\begin{array}{l}\text { 7a. Yes } \\
\text { 7b. Yes } \\
\text { 7c. Yes } \\
\text { 7d. Yes } \\
\text { 7e. Yes }\end{array}$ & $\begin{array}{l}\text { 7a. Yes } \\
\text { 7b. Yes } \\
\text { 7c. Yes } \\
\text { 7d. Yes } \\
\text { 7e. Yes }\end{array}$ \\
\hline
\end{tabular}




\begin{tabular}{|c|c|c|c|c|}
\hline $\begin{array}{l}\text { Entry point } \\
\text { and seat }\end{array}$ & $\begin{array}{l}\text { 8a. Minimum } 455 \mathrm{~mm} \text { wide and } \\
610 \mathrm{~mm} \text { height }\end{array}$ & 8a. Yes & 8a. Yes & 8a. Yes \\
\hline $\begin{array}{l}\text { Sand table I } \\
\text { Play table }\end{array}$ & $\begin{array}{l}\text { 9a. Minimum size } 760 \mathrm{~mm} \quad x \\
430 \mathrm{~mm} \times 610 \mathrm{~mm}\end{array}$ & 9a. NA & 9a. NA & 9a. NA \\
\hline $\begin{array}{l}\text { Stationary play } \\
\text { equipment }\end{array}$ & $\begin{array}{l}\text { 10a. Use zone shall extend no } \\
\text { less than } 1830 \mathrm{~mm} \text { from all } \\
\text { sides }\end{array}$ & 10a. Yes & 10a. Yes & 10a. Yes \\
\hline $\begin{array}{l}\text { Rotating play } \\
\text { equipment }\end{array}$ & $\begin{array}{l}\text { 11a. Use zone shall extend no } \\
\text { less than } 1830 \mathrm{~mm} \text { from all } \\
\text { sides } \\
\text { 11b. Rotating equipment with } \\
\text { platform }>508 \mathrm{~mm} \text { diameter, } \\
\text { the use zone shall not } \\
\text { overlap with another use } \\
\text { zone } \\
\text { 11c. Rotating equipment with } \\
\text { platform <508mm diameter, } \\
\text { the use zone may overlap } \\
\text { with another use zone if the } \\
\text { height is less than } 760 \mathrm{~mm}\end{array}$ & $\begin{array}{l}\text { 11a. Yes } \\
\text { 11b. Yes } \\
\text { 11c. No }\end{array}$ & $\begin{array}{l}\text { 11a. Yes } \\
\text { 11b. Yes } \\
\text { 11c. No }\end{array}$ & $\begin{array}{l}\text { 11a. NA } \\
\text { 11b. NA } \\
\text { 11c. NA }\end{array}$ \\
\hline To-fro swings & $\begin{array}{l}\text { 12a. Front and rear of use zone } \\
\text { shall be minimum } 2 x \\
\text { distance of vertical distance } \\
\text { from protective surface to } \\
\text { pivot point of the swing } \\
\text { 12b. } \begin{array}{l}\text { No other structure shall } \\
\text { overlap the front to rear use } \\
\text { zone } \\
\text { 12c. Use zone surrounding to the } \\
\text { swing shall at least } 1830 \mathrm{~mm} \\
\text { distance at all side }\end{array} \\
\end{array}$ & $\begin{array}{l}\text { 12a. Yes } \\
\text { 12b. Yes } \\
\text { 12c. Yes }\end{array}$ & $\begin{array}{l}\text { 12a. Yes } \\
\text { 12b. Yes } \\
\text { 12c. No }\end{array}$ & $\begin{array}{l}\text { 12a. NA } \\
\text { 12b. NA } \\
\text { 12c. NA }\end{array}$ \\
\hline Rotating swing & $\begin{array}{l}\text { 13a. No other structure shall } \\
\text { overlap the front to rear use } \\
\text { zone } \\
\text { 13b. Use zone surrounding to the } \\
\text { swing shall at least } 1830 \mathrm{~mm} \\
\text { distance at all side }\end{array}$ & $\begin{array}{l}\text { 13a. Yes } \\
\text { 13b. Yes }\end{array}$ & $\begin{array}{l}\text { 13a. NA } \\
\text { 13b. NA }\end{array}$ & $\begin{array}{l}\text { 13a.NA } \\
\text { 13b.NA }\end{array}$ \\
\hline $\begin{array}{l}\text { Rocking/spring } \\
\text { equipment }\end{array}$ & $\begin{array}{l}\text { 14a. Standing rocking/spring } \\
\text { equipment, the use zone } \\
\text { cannot overlap with any } \\
\text { other equipment. The } \\
\text { distance shall not less than } \\
2130 \mathrm{~mm} \\
\text { 14b. Use zone may overlap for } \\
\text { sitting type rocking } \\
\text { equipment if the play surface } \\
\text { is } 760 \mathrm{~mm} \text { or less. The } \\
\text { distance shall not less than } \\
1830 \mathrm{~mm}\end{array}$ & $\begin{array}{l}\text { 14a. NA } \\
\text { 14b. Yes }\end{array}$ & $\begin{array}{l}\text { 14a.NA } \\
\text { 14b. NA }\end{array}$ & $\begin{array}{l}\text { 14a. NA } \\
\text { 14b. No }\end{array}$ \\
\hline $\begin{array}{l}\text { Playground } \\
\text { surface }\end{array}$ & $\begin{array}{l}\text { 15a. Shall meet the safety and } \\
\text { impact } \\
\text { requirement }\end{array}$ & 15a. Yes & 15a. No & 15a. Yes \\
\hline
\end{tabular}




\begin{tabular}{|l|l|l|l|}
\hline Percentage Compliance to Standard & $\begin{array}{l}21 / 35 \\
=60 \%\end{array}$ & $\begin{array}{l}23 / 35 \\
=65.7 \%\end{array}$ & $\begin{array}{l}20 / 35 \\
=57.14 \%\end{array}$ \\
\hline
\end{tabular}

The above table's result revealed that the level of compliance of the inclusive public playground in Malaysia with the MS 966:2017: Playground Equipment - Safety performance for public use standard are still at the moderate quality of $57.14 \%$ to $60 \%$. Four analytical issues in the Malaysian Public Playground are identified; age classification, accessibility on the playground such as accessible route, availability of ramp for elevated play area, and transfer system and suitability of play equipment in the playground design are still unclear. First, some of the inclusive public playgrounds, such as Playground B and Playground $\mathrm{C}$, are not designed according to the intended user or age group. Most equipment is placed together, and it was not reliable to assume that all children were mature enough to consider which equipment had been designed for their age group. This will cause high play risk to children as toddlers, and school-age children are dramatically different in terms of physical size, capability, and even cognitive capability.

Next, the second analytical issue found in the study that violates the standard is the accessibility on the playground. Children with disabilities can be denied their right to play when there are none of the elements that accommodate accessibility to elevated play areas such as in Playground $A$. There is no ramp or any other means of access for children with disabilities to the elevated play area, limiting the children only to the ground play equipment.

Besides, the non-existence of an accessible route in the Playground B could be the major barrier in creating an inclusive playground for children with all types of abilities. Even though most of the play equipment design is disabled friendly, accessibility from the parking lot to the playground should be the first concern in creating an inclusive playground. The existence of bollards on the route makes it difficult and almost impossible for children with mobility aid to reach the play area.

Lastly, the third analytical issue found in the study is the suitability of the play equipment used on the playground. For example, in Playground C, there are not many types of play equipment offered on the playground, which may lead children with no disabilities to lose their interest in playing on the playground due to lack of challenging opportunities in the play equipment. There should be a balance between safety and

\subsection{Analysis Based on Universal Design Principle}

Table 3 indicates that some of the Universal Design principles have been violated in the inclusive playground design. Principles that define flexibility in use, tolerance of error, low physical effort, and size and space for approach and use that suppose to allude in the playground design has not complied. There is lacked in the flexibility of use factor in all three playgrounds. The current design of Playground A offers limited opportunities for the use of children with disabilities as most of the play components are difficult and inaccessible to use without assistance. While in Playground $B$ and Playground $C$, the playgrounds do not provide multi-use opportunities for all age groups. 
Therefore, the sense of safety in high activity and challenging activities, especially among toddlers and preschool children, is a concern. Besides, the playgrounds also do not perceive a good tolerance of error in the playground design as there are no warning signs allocated at the play component. It is too risky for the children when the playground is not covered by appropriate fall surface material. The use of concrete as a fall surface in Playground B will cause injuries or even fatal whenever the kids fall from the high place. In addition, it is noted that children without disabilities also required much physical flexibility and exertion to move around from level to level in Playground $A$ as the - design of the play equipment is difficult and complex. Method of use in the playground is severely limited to non-disabled children. Furthermore, most of the playground does not achieve the last principle in the UD concept: size and space for approach and use. There is no age classification adopt into Playground $B$ and Playground $C$ to accommodate the variation of size, handgrips, and fall height. In a nutshell, the design of all three playgrounds is still not enough to perceive all the Universal Design principle to be an appealing design of an inclusive playground

Table 3: Integration of UD principle in an inclusive public playground in Malaysia

\begin{tabular}{|c|c|c|c|c|}
\hline & & $\begin{array}{c}\text { Playground } \\
\text { A }\end{array}$ & $\begin{array}{l}\text { Playground } \\
\text { B }\end{array}$ & $\begin{array}{l}\text { Playground } \\
\text { C }\end{array}$ \\
\hline & $\begin{array}{l}\text { Score / Percentage of } \\
\text { compliance }\end{array}$ & $28 \%$ & $45 \%$ & $57 \%$ \\
\hline \multirow{8}{*}{ 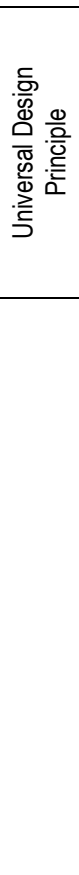 } & Equitable use & & $\checkmark$ & $\checkmark$ \\
\hline & Flexibility in use & & & \\
\hline & Simple and intuitive use & & $\checkmark$ & $\checkmark$ \\
\hline & Perceptible information & $\checkmark$ & & \\
\hline & Tolerance of error & & & $\checkmark$ \\
\hline & Low physical effort & & $\checkmark$ & $\checkmark$ \\
\hline & $\begin{array}{l}\text { Size and space for approach and } \\
\text { use }\end{array}$ & $\checkmark$ & & \\
\hline & Note & $\begin{array}{l}\text {-Multi play mode } \\
\text { are available but } \\
\text { CWD's access } \\
\text { are only limited } \\
\text { to ground play } \\
\text { activities } \\
\text {-Complex play } \\
\text { equipment cause } \\
\text { difficulties in } \\
\text { CWDs. Most play } \\
\text { equipment } \\
\text { require much } \\
\text { physical exertion }\end{array}$ & $\begin{array}{l}\text { - No age } \\
\text { segregation. } \\
\text { Some children } \\
\text { might face } \\
\text { difficulties due to } \\
\text { 'scale problem' } \\
\text { - Swings are } \\
\text { segregated from } \\
\text { the accessible } \\
\text { route } \\
\text { - Fall risk is high } \\
\text { as the } \\
\text { underneath of } \\
\text { playground is } \\
\text { covered by } \\
\text { concrete. EPDM } \\
\text { are only provided } \\
\text { at the end of slide }\end{array}$ & $\begin{array}{l}\text { No age } \\
\text { segregation. } \\
\text { Some children } \\
\text { might face } \\
\text { difficulties due to } \\
\text { 'scale problem' } \\
\text {-No sign or play } \\
\text { instruction } \\
\text { provided }\end{array}$ \\
\hline
\end{tabular}




\subsection{Conclusion}

Children with disabilities require a specially designed playground to develop their abilities. Playground $A$, Playground $B$ and Playground $C$ were all designed with particular focus on inclusiveness in the study. However, the study's result revealed that both MS 966:2017 : Playground Equipment - Safety performance for public use standard and Universal Design principle have not yet been achieved thoroughly. Besides, even though Playground B's design met most of the inclusive design approach requirements, the fact that the route that leads to the playground is not appropriate or inaccessible. This limits the opportunities for children with disabilities, especially those with mobility devices, to access the playground. Overall, when these playgrounds are evaluated, Playground $C$ is the most appropriate example of playground aim for disabled children that comply with most of the ADAAG and Universal Design principles.

\section{Acknowledgements}

The authors would like to express gratitude to the Faculty of Architecture, Planning, Surveying, Universiti Teknologi MARA, and Shah Alam for all the facilities they provided. Acknowledgment is also given to all respondents who are involved in this research.

\section{Article Contribution to Related Field of Study}

Through this study's findings, the paper pointed out that an inclusive play environment could be developed if integrating the UD principle and applicability of the current Malaysian Standard is further focused on the design. It also fulfills the established need to research how outdoor play inequity among children with disabilities can be addressed.

\section{References}

Ayatac, H. (2017) 'No "Obstacles" In Playgrounds That Are Not Only Accessible But Also Inclusive,' International Journal of Architecture \& Planning, 4(2), pp. 1-14. DOI: 10.15320/ICONARP.2016120233.

Bakar, J. A. (2002) A Design Guide for Public Parks in Malaysia. First Edit. Edited by M. F. Othman. Kuala Lumpur, Malaysia: Universiti Teknologi Malaysia.

Connors, C. and Stalker, K. (2007) 'Children 's experiences of disability : pointers to a social model of childhood disability,' Journal of Disability \& Society, 22(1), pp. 37-41. DOI: 0.1080/09687590601056162.

Clarke, D. H. (2006) Preventing Social Exclusion of Disabled Children and Their Families. The United Kingdom.

Ellis, M.J. (1973). Why people play. Englewood Cliffs, NJ: Prentice-Hall

Fernelius, C. L. . (2017) Evidence-Based Practices For The Design of Inclusive Playgrounds That Support Peer Interactions Among Children With All Abilities. Utah State University. 
Follette, M., James, L. and Ronald, L. (1998) The Universal Design File: Designing for People of All Ages and Abilities. Revised Ed. Washington, DC. PUB: NC State University.

Goltsman, S. and Driskell, D. (1992) 'Beyond the Curb Cut,' Journal of Applied Sciences Research, 1(84), pp. 12.

Houle, R. (2002) A Post-occupancy Evaluation of Children's Needs in The Kinsmen Play Village from a Universal Design Perspective. The University of Manitoba.

Isa, Zanol, Halmi, Alauddin, and Nawi. (2016) 'Provisions of Disabled Facilities at The Malaysian Public Transport Stations,' in MATEC Web of Conferences, pp. 1-8.

Islam, M. R. (2015) 'Rights of the People with Disabilities and Social Exclusion in Malaysia', International Journal of Social Science and Humanity, 5(2), pp. 1-7. DOI: 10.7763/IJSSH.2015.V5.447.

Jafari, M. (2014) Assessing Universal Design Principle Application on Children Playground at Lake Titiwangsa Park, Kuala Lumpur. Universiti Putra Malaysia.

Jing, C. C. (2019) 'Malaysians ' Attitudes toward People with Disabilities,' Journal of Arts \& Social Science, 2(2), pp. 27-65.

Ling, C. K. et al. (2019) 'Applicability Of Malaysian Standards ( Ms 966 ) In Benefiting Health And Safety Of Children In Malaysia', Journal of Alam Cipta, 12(2), pp. 1-7

Malaysian, G. (2018) PERSONS WITH DISABILITIES ACT 2008 ( ACT 685).

Md.Saaid, A. H. (2016) Exploring Aspect of Design and Safety of Children Playgrounds in Malaysia. Universiti Sains Malaysia.

Mokhtar, K. A. and Tah, I. H. M. (2016) 'Malaysia's ratification of the un convention on persons with disabilities' rights, International Journal of Business, Economics and Law, 11(4), pp. 83-87.

Preiser, W. F. . and H.Smith, K. (2011) Universal Design Handbook. Second Edi. New York: Mc Graw Hill.

Prellwitz, M. (2007a) Playground Accessibility and Usability for Children with Disabilities Experiences of children, parents, and professionals. The Luleå University of Technology.

Prellwitz, M. (2007b) Usability of playgrounds for children with different abilities, Wiley InterScience.

Ripat, J. and Becker, P. (2012) 'Playground Usability : What Do Playground Users Say ?', Journal of Design and Built Environment 19(1), pp. 144-153. DOI: 10.1002/oti.1331.

Social Welfare Department (2019) Statistic of People with Disabilities in 2019.

Skulski, J. (2014) Designing for Inclusive Play: Applying the Principles of Universal Design to the Playground, National Center on Health, Physical Activity and Disability (NCHPAD).

Story, M. F. (1998) 'Maximizing Usability : The Principles of Universal Design,' Journal of RESNA, 4(12), pp. 3741. DOI: $10.1080 / 10400435.1998 .10131955$.

Talay, L., Akpinar, N. and Belkayali, N. (2010) 'Barriers to playground use for children with disabilities : A case from Ankara, Turkey,' Journal of Agricultural Research, 5(May), pp. 848-855. DOI: 10.5897/AJAR09.779. 
United Natuon. (1990) Convention on the Rights of the Child. NewYork City.

UNICEF. (2018) UNICEF Inclusive Playground Initiative, UNICEF. Available at: https://autismmalaysia.com/2018/10/unicef-inclusive-playground-initiative/ (Accessed: 5 October 2019).

World Health Organisation. (2018) Global action plan on physical activity 2018-2030. Switzerland.

Yusof, L. M. (2016) Universal Design and Professional Practice Obligations in Malaysian Domestic Housing. Deakin University.

Zain, N. M., and Mokhtar, S. A. I. (2012) Playground Safety, My Health, Kementerian Kesihatan Malaysia. Available at: http://www.myhealth.gov.my/en/playground-safety/ (Accessed: 20 November 2019). 